\title{
MARGINALIZATION AND SIGNIFICANCE OF POWER IN ACCOUNTING; A CASE STUDY OF THE BETAWI TRIBE SOCIETY IN INDONESIA
}

\author{
Marko S. Hermawan * \\ International Business Management Program, Management Department, BINUS Business \\ School Undergraduate Program, Jakarta 10270, Indonesia.
}

Delvy

Accounting Department, BINUS Graduate Program and Master of Accounting Bina Nusantara University, Jakarta 11480, Indonesia.

\section{Tri Hapsari}

Accounting Department, BINUS Graduate Program and Master of Accounting Bina Nusantara University, Jakarta 11480, Indonesia.

${ }^{*}$ Corresponding Author

\begin{abstract}
The Betawi people, who have been considered the original ethnic groups in Jakarta, are felt to be decreasing and even marginalized. In fact, with the development of DKI Jakarta as the capital city, it is felt that it is increasing from year to year. With their proximity to the central government, they should be able to become the most advanced tribes and have a better life and be famous compared to other tribes in Indonesia. This study aims to provide an overview and understanding of the causes of the retreat of the Betawi people in Jakarta. This study uses a critical methodology (critical inquiry) with a qualitative approach. The results of this study indicate the importance of the government's role in preserving and maintaining the increasingly marginalized Betawi culture. The young Betawi generation is one important aspect to develop their awareness in financial management to preserve the Betawi people in the land of Jakarta and foster a sense of being active in advancing the Jakarta administration.
\end{abstract}

Keywords: marginalization, power, accounting, Betawi

Cite this Article Marko S. Hermawan, Delvy and Tri Hapsari, Marginalization and Significance of Power in Accounting; a Case Study of the Betawi Tribe Society in Indonesia, International Journal of Management 11(12), 2020, pp 1253-1265.

http://iaeme.com/Home/issue/IJM?Volume=11\&Issue=12 


\section{INTRODUCTION}

Studies in accounting and sociology have developed into various context within a particular setting, such as its relationship to people's behavior (Breton, 2018), organizational culture (Roslender, 2002) and national setting (Ahrens \& Mollona, 2007; Wickramasinghe \& Hopper, 2005). As Breton (2018) argues, accounting is a sociological phenomenon, in that one needs to distinguish its parameter. In a specific case, accounting and marginalization is one topic that is closely related between one dominant power of a community and other less dominated ones. According to the Indonesian Dictionary (KBBI, 2020), marginalization is a limiting effort; restrictions on certain groups. "In a broader sense, it means the pressure or restriction on a person or group or something in various aspects which causes the object of this pressure or restriction to be removed until it is at the boundary or edge or edge. Marginalization does not exist by itself but is formed with and through structured and neat planning. It is conducted by the 'power' who collaborate with 'ideological groups' and can be used as a means of oppressioncoercion.' Such collaborations can be concrete and overt, or invisible but exist. Moreover, the bonds that collaborate are mutual interests and benefits (Pellokilla, 2020).

Post-independence in 1945, Jakarta was flooded with immigrants from all over Indonesia, which made the Betawi people - in whatever sense - lived as a minority. In 1961, the Betawi 'tribe' comprised approximately $22.9 \%$ of Jakarta's 2.9 million population. They are increasingly being pushed to Jakarta's outskirts and are even busy being evicted and driven out of Jakarta. Although 'ethnic' Betawi people have never been evicted or evicted from Jakarta, the marginalization process is a phenomenon that the Betawi ethnic group is 'quite left behind'. This backwardness can be reflected in the phenomenon of the assimilation process of various tribes in Indonesia until now, and it is through this long process that the Betawi 'tribe' is present in the Archipelago.

Accounting and its practice are areas that involve and are heavily influenced by local organizations, people, the environment, and ideology (Darmayasa \& Aneswari, 2015). Accounting practices that occur in the Betawi community or Betawian accounting practices can be seen from transactions or events related to the Betawi people's economic, social, and political life during the Dutch colonialism era. Accounting knowledge in the Betawi people emerged from the Dutch colonialism system's implementation, and accounting had an important role in prices, costs, and profits. Understanding the Betawi people's accounting knowledge was closely related to social problems related to private land, which required much labor and caused much exploitation outside of humanity (Darmayasa \& Aneswari, 2015). This condition confirms that (conventional) accounting is built with a similar premise to reinforce injustice so that it becomes a myth because the 'normality' viewpoint of accounting practice through si Pitung is the essence of breaking into normality (Kamayanti, 2017).

Based on this background, we start with a question of 'What are the accounting implications for the marginalization of the Betawi people?' This can be seen from the epistemology of fundamental accounting. Accounting treatment that is neutral, accountable, and accountable may only serve those who have certain interests, in this case increasing the benefits of individuals, their groups, and certain companies. This may not be appropriate for other stakeholders, who do not deal directly with financial reporting. Referring to Laughlin's (1999) and Roslender (2002), critical theory is a vehicle that can be used to understand reality through the transformation in an institution caused by dissatisfaction with current conditions. Betawi society studies must be critical because research on this topic is still very little. 


\section{LITERATURE REVIEW}

In a study conducted by Pratama \& Utomo (2018), Indonesia's accounting research is dominated by quantitative research $(78 \%)$ flourished by agency-based theory. The research scope is dominated by the private sector with financial accounting and capital markets and examining corporate objects. The philosophy of science as the basis and direction of science development: an approach with a positive accounting methodology is still under criticism. The main criticism of the positive accounting methodology. The concept of a positive theory is drawn from an ancient philosophy of science and is, in any case, an unsuitable term because the theory of empirical science does not make a positive statement of "what is." Most of the theories are 'unscientific' (Mardiyah, 2003).

On the other hand, the development of accounting and sociological research in Indonesia can be said to be still in the stage of looking for 'identity', where the topics addressed are still limited to an interpretive review of social phenomena and modern society in the context of modern business. Sukoharsono (2005) presents a sociological perspective in accounting research. He argued the importance of expanding the scope of qualitative accounting research into the realm of critical inquiry in the context of technological change, labor transformation processes, and corporate culture. The enthusiasm to review these paradigms is expected to enrich the discussion of accounting from a sociological perspective. This paper contributes to the extent of accounting epistemology that constitutes Indonesia's sociology and cultural context, in this case, the marginalization of the Betawi tribe in the Jakarta area.

Accounting has more meaning than just financial statements because the development of accounting science is not only limited to financial accounting or based on numbers. Morgan (1988) through the Escher lithograph crystal ball illustration, a person's perspective is a reflection of what he sees in front of the crystal ball. He would observe, do thoughts and decisions 'only' what he could see from the front side of the crystal ball. But he forgot that the crystal ball was round and had a holistic perspective on all sides of the ball. What Morgan reveals is an epistemology in which the nature of accounting is based on certain interests, especially shareholders and the company itself. However, other interests, especially the surrounding community, cannot be translated and explained quantitatively and qualitatively by a holistic accounting epistemology. This results in the accounting paradigm tend to be 'misused' to master other perspectives in social society.

Within the context of the marginalization of the Betawi tribe, it is clear that their control of land and property rights has been easily displaced by the transactional activities of the very fast development in Jakarta, especially since the era of Governor Ali Sadikin's leadership. These transactional activities promote unilateral benefits from developers, developers, and investors who invest a lot of their capital in Jakarta. Also, the Betawi culture, which does not have a sense of belonging and tends to accept and be kind to immigrants, causes them to be marginalized and move from their ancestral lands in Jakarta. However, other aspects beyond numbers can influence accounting practices, such as psychology, politics, culture, sociology, and other aspects outside of these numbers. It is very naive if we think that science can only be developed through one paradigm. According to the authors, multi-paradigm-based science needs to be developed in science development, especially in Indonesia's accounting practices. A solution in the development of science can be developed from one paradigm but must use various paradigms.

The theory of marginalization, according to Janice E. Pearlman (1975) is divided into four. Marginalization is due to economic, cultural, political, and social reasons. We will discuss the difference between these marginalizations from the first, marginalization due to the economy. This marginalization occurs due to low-income citizens, such as lack of income, 
unemployment, and unemployment so that they become poor. Usually, by being marginalized economically, they will also experience other dimensions of marginalization.

Second is cultural marginalization; this occurs because of discrimination due to ethnicity, race, custom, and religion. Nevertheless, Janice Perlman emphasizes skin color, making it difficult to have a job and live. As well as urbanites who are only given to living in the suburbs and even illegal to live in, it is very different from the indigenous people who can live in urban centers.

For people who do not understand politics and their rights, if other parties take advantage of this situation, this community will automatically be oppressed. Powerless people will be marginalized by themselves, and this is what is called political marginalization, where they do not get political rights and the opportunity to have a voice in expressing opinions.

Socially marginalized are experienced by those born in urban areas, but they seem to live in isolation because they cannot afford and do not get space to use resources. This is due to poor education and health facilities, low cost of living, and little access to services they provide.

What about the Betawi people who have lived in Jakarta for a long time? Since 1966 the election of the Governor of Jakarta, Ali Sadikin, the development that continues to be carried out by the government has succeeded in changing the face of the city of Jakarta to become a metropolitan city which has become the center of industrial trade activities, government, and a gathering place for ethnic groups. However, the development, which was getting more intense at that time, was not felt by all groups, especially the Betawi people as Jakarta's original people. The Betawi people's marginalization starts from giving up their land to be sold to develop the City of Jakarta, the flow of urbanization, and the marginalization of the economy caused by the development up to their business profits. Factors that constitute marginalized Betawi community include internal factors within the Betawi community, such as their low quality of life and strong religious influence. The external factors are the number of evictions for development and the number of urbanization. The impacts of marginalization include social, economic, and cultural impacts (Lukmansyah, 2017).

\section{RESEARCH METHODS}

This research can be categorized into a critical area. Referring to Laughlin (1999) opinion as quoted by Roslender (2002), critical theory is a vehicle that can be used to understand reality through the transformations that occur in an institution dissatisfaction with current conditions. Thus, researchers assume that critical theory can improve the current reality if we can make critical thinking changes. This has been done in research that criticizes accounting education at vocational colleges to improve the philosophy, education system, and learning materials for accounting education at vocational colleges in Indonesia (Ekasari, 2013).

This research uses qualitative research methods with interpretivism paradigm and ethnographic research theory. Qualitative methods to understand the phenomena experienced by research subjects can be in behavior, perception, motivation, and action holistically and descriptions in words and language in a natural context and by utilizing natural methods. This method aims for a deep understanding of reality (Mursy, Triyunono, \& Rosidi, 2014). With this research, the relation is that the Betawi Ethnic phenomenon is a creolization that cannot be found in other ethnic groups. Following the research objectives that want to understand Betawi customs, customs, or culture, it is necessary to choose the right paradigm to achieve the research objectives. Like Interpretivism to understand ethnic, financial inclusion, Betawi, it is not enough to know their history, but it requires more recognition of their values, beliefs, and traditions. 
Meanwhile, the definition of ethnography is a description of cultural systems or cultural aspects based on field research in which the researcher looks directly at the community being studied to describe the social context, relationships, and processes that are relevant to the problem being studied. This is following the research objectives, which discover the development of Betawi ethnic, financial inclusion by extracting information from the Betawi ethnic population to gain a holistic understanding. This understanding is in line with realist ethnography, which describes informants' situation objectively based on information obtained directly in the field.

\section{DISCUSSION}

\subsection{ACCOUNTING AND POWER}

In accounting, the relationship between accounting and power has been done in critical analysis. Wickramasinghe said that the principles of accounting and power are influenced by social, institutional, political, and cultural factors. The basic questions of this critical philosophical understanding; is accounting a power or the subject of power? Wickramasinghe argues that if accounting is a source of power, we must investigate its source and how that source can affect an organization / other institution. Conversely, if accounting is said to be the subject of power in an organization, then we must observe how accounting interacts with that power (Wickramasinghe P.D., 2006).

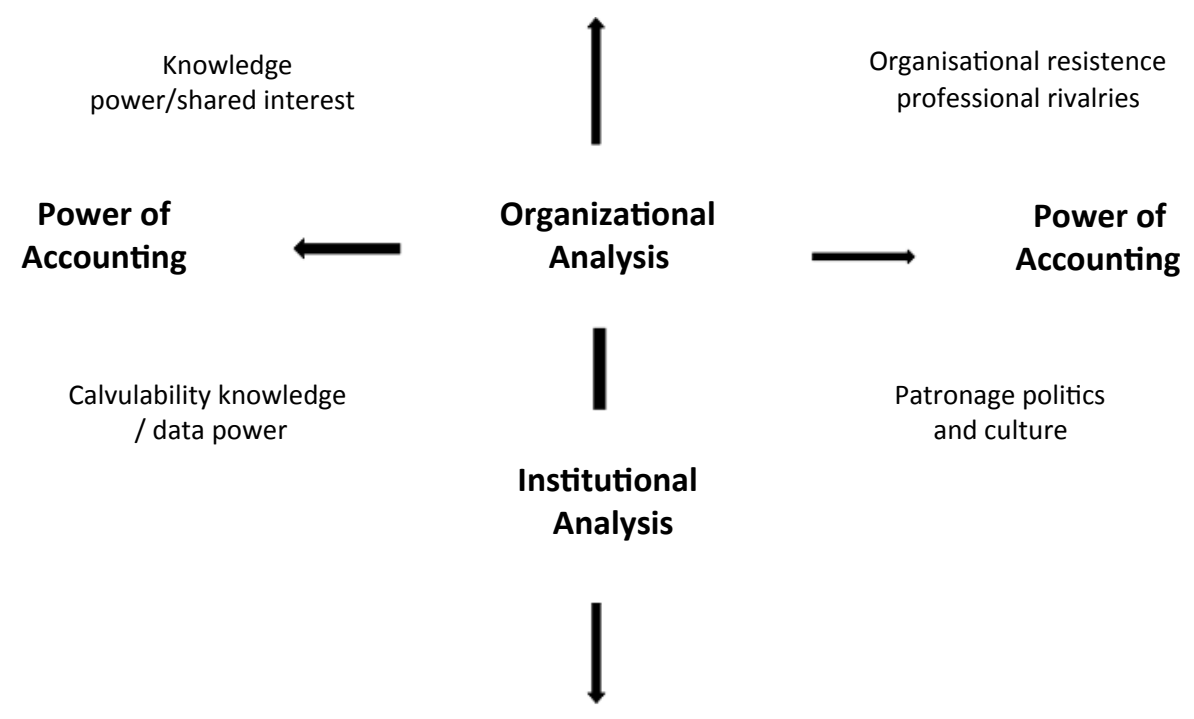

Figure 1.Researching Power in Accounting (Wickramasinghe, 2006)

Accounting can be stated as part of modernism because Positive Accounting Theory (PAT) assumes that morality is not related to PAT since the 19th-century positivism in the social sciences has been deemed inadequate for understanding man and society. Positivism is considered the root of modern totalitarian dehumanization and domination; in other words, it can be said that positivism is the soul of modernity, while modernity itself has eliminated aesthetics and morals. Indirectly the accounting literature has transformed capitalism, materialism, individualism, and secularism (Ekasari, 2013).

\subsection{BETAWI AND ITS HISTORY}

Betawi ancestors began to be formed since Jakarta's founding, which was previously called Batavia by the Dutch. Their gathering dates from the 17th Century to Batavia from the southeast and south Asia, Portugal and Bali's Dutch territory, and other islands on the Indonesian peninsula. Their gathering served as slaves and soldiers for the Dutch colonialists and servants 
for other influential foreign populations such as China. There is the fact that the Dutch expelled the native Javanese and made the Betawi people who came as the original inhabitants of Batavia.

Until 1828, the collection from various regions was stopped because it was considered inefficient. So it is with the slave trade. These changes increased the contact and mix between ethnic groups in Batavia and increased culture's creolization into a new ethnic group called Betawi. So that Sundanese, Ambon, Chinese, Indian and other languages identify themselves as Betawi, which is estimated to be 2.5 million people.

During the period of slavery, they had little access to modern education and just followed their traditions. For Muslims, they struggled to get closer to the colonial elite and its education system. Their education policy prefers to send their children to pesantren, a school dedicated to Islamic teachings. As a result, none of them became the Indonesian elite in Jakarta even after independence in 1949. So that most of them are Javanese, and some come from other islands in Indonesia.

In the next two decades, the desire to develop a unique Indonesian national identity is hampered by reflections of the post-colonial period and all the unpleasant memories, including the Betawi and their backgrounds related to slavery. In contrast, during the pre-colonial golden age, most used general concepts of religion and spirituality, which were meant to serve as a national identity source. Thus after nearly 350 years of foreign domination, post-colonial leaders largely defined Indonesia in pre-colonial terms. Is it the post-colonial development originating from the pre-colonial power of the Indonesian people, or rather the colonial boundaries that have contributed to Indonesia's national identity that existed in the early 1960s?

In the early post-colonial period, especially in the city of Betawi, the so-called Betawi Cities tended to hide their identities in public because of the negative stereotypes attributed to them to reduce social discrimination and achieve high social mobility. Jakarta began to change to give special attention and promotion to ethnic Betawi. There are many differences between starting to revive and rebuild culture and to increase the Betawi identity. Research on their culture began with the steps taken to promote Betawi culture. Special possible areas were created to allow maintaining customs and enhancing traditional practices. Even at events related to Jakarta, such as Jakarta's anniversary, events in Jakarta, dance, drama, and Betawi music is performed throughout the city of Jakarta sponsored by the Jakarta city government. Every year there is also a contest "Abang dan None Jakarta" held by the Governor of Jakarta, which is a competition for all young people in Jakarta, regardless of their ethnic identity, can participate, but all candidates must prove a general knowledge of Betawi traditions, history, society, and politics in Jakarta.

The ethnic problem does not stop even though it has been 20 years of independence, and after colonialism, it takes a stronger symbol than the pre-colonial legacy, which was allegedly being considered by the main president Soekarno. Jacqueline argues that state institutions find social and political potential lies in the concept of the creation of the Betawi group's identity. There are different reasons for this potential, especially in multiethnic and post-colonial contexts. One of the reasons, during the colonialization, many cultural features, both foreign and indigenous, were originally incorporated into the Betawi ethnicity. Furthermore, it is known that some of the Betawi ancestors, at some stage, did not creolize but maintained their identities, such as Sudan, China, and others. Another more important reason, as a creolized group, Betawi represents many ethnicities, and at the same time creating 1 group, one identity based on the diversity of ethnic backgrounds. The representatives of these two things fit in with the national motto of Bhinneka Tunggal Ika, which is an important element of Pancasila - the five principles of the Indonesian state ideology. 
Thus, through the Betawi ethnicity, it can be proven that ethnic diversity does not hinder the development of togetherness. On the other hand, the Betawi people can prove that unity in diversity can work. With the same goal, they integrated various ethnic cultures from diverse backgrounds. They became Betawi, another ethnic group in Indonesia, united by a national culture that integrated different ethnic traditions peacefully and was successful.

In post-colonial Indonesia, it was hit by ethnic and religious conflicts, and Betawi differences could be included in the context of national trans-ethnic integration and functioned as a counterbalance to the fear of national disintegration. The Betawi people are not mixed, they are not Javanese, and because of this, they do not belong to the community group that has long been the most dominant and politically existed. However, this Javanese domination began to decrease due to the democratization, liberalization, and decentralization of the Indonesian political system, although their desire is still strong to fight the balance of Javanization in Indonesia and the capital city Jakarta.

By promoting the Betawi people's Creole culture, the state can do so without neglecting other ethnic groups. Because the Betawi people are mixed in their origins, their culture can be recognized and introduced as an ethnic tradition distinct from Indonesia, making it possible for all ethnic groups to recognize their culture and characteristics, divided into Betawi. Thus, through ethnic or transethnic Betawi culture, it can be an example and convey both ethnicity and transethnicity at the same time. Therefore, it is applied and used by state institutions in a variety of ways to enhance Jakarta's transethnic and national characteristics to reduce interethnic conflict. One governor said that in Jakarta, the Betawi native to the capital is the host of various cultures living in Jakarta, formed from a fusion of Indonesian races, ethnicities, and cultures in the 19th Century.

Moreover, a promoter also said that Betawi is like 'Gado-Gado' (a Betawi dish consisting of various vegetables and peanut sauce) are mixed in with various ingredients and make this mixture a very tasty and unique food. Like Indonesia, there are many different cultures, which together make Indonesia beautiful. Betawi people are in it and belong to part of Indonesia, diverse in their origins but united as Indonesians.

Due to the status of the original residents of Jakarta, they enter the capital city with various ethnic customs and traditions. Thus, by promoting Betawi, the city of Jakarta also maintains authenticity and traditional traditions. Because this ethnic tradition was built on cultural concepts and creole characteristics, everyone in Jakarta can obey it regardless of different ethnic backgrounds.

The fact that the Betawi region coincides with the Indonesian capital center helps to attach to Betawi culture's national meaning and function and its characteristics. Betawi people are getting stronger in line with their local and regional awareness because their characteristics are clearer so that they are identified as residents by other residents. One example of his observation was when, in 2001, thousands of people from East Java threatened to overthrow Jakarta from the president's overthrow. Moreover, to prevent the overthrow, Betawi residents organized Betawi militias to defend the city against intruders. Betawi people present themselves as defenders of the city and region for the national interest. While heavy tanks and thousands of soldiers and police filled the streets and guarded the parliament building, Betawi "soldiers" wore traditional uniforms and weapons and how themselves according to their true identity. One of the soldiers also said that they, as Betawi people, must defend their city. They own this city, and therefore they have to make sure that everyone can feel safe in their city. They do not want outsiders to damage Jakarta's reputation. This is important for all of Indonesia because Jakarta is the capital city of Indonesia.

There has been a shift in attitude regarding the Betawi people's role during the Dutch colonial period and the struggle for independence. Some of its anti-colonial movements were 
largely ignored by the early post-colonial elite, who declared themselves the nation's emancipation and the Indonesian mind. Nevertheless, since the late 1960s, when post-colonial nation-building could not be built solely on the pre-colonial ground, the Betawi were rerespected as a group that maintained Indonesia's traditions and dignity on its heyday and helped restore Indonesia's prowess. In the context of the story about Betawi anti-colonial heroism, it was found and brought into the public sphere. For example, the legend of si Pitung, a famous Betawi hero, claimed to have fought and humiliated the Dutch by using his spiritual power, intelligence, and intelligence.

As an ethnic group, Betawi reassess their community concept to advance as a community that has long been neglected and socially disadvantaged. They are increasingly aware of and exploiting the potential of their Betawi identity and culture with their new (special) status with great enthusiasm regarding who and what Betawi is. On the one hand, the differences between ethnicities are also shown to show the abundance of Betawi cultural wealth. They also invite newcomers to join in to expand their influence. Groups in the city that once rejected being Betawi people with better lives are called urban Betawi people who are now included as authentic Betawi because they have expertise regarding Betawi traditions that need to be known and practiced in public to introduce themselves as authentic Jakartans.

On the other hand, Betawi people whose lives are more traditional on Jakarta's outskirts called the Betawi margins, often deny urban Betawi's status due to their lack of authenticity. Many of the Betawi outskirts have now begun to accept the 'Jakartans' as the true Betawi because Betawi is the most actively involved in promoting the whole of Betawi. Many ethnic Chinese claim Betawi identity to prevent discrimination as they have experienced joining the Betawi association and actively participating in Betawi arts development and promoting the Betawi tradition.

Some of Betawi's positive transethnic connotations are mixed, somewhat contrary to the many traditional Betawi people who are often seen as not dynamic, and it is often heard that Betawis always live only among them. This shows that creolization is not always sustainable in the interaction and mixing between ethnic groups. Creolization can end. Nevertheless, the underlying concept of culture and identity may remain effective, called the creole continuum (creole sequence). Regarding culture and identity, it is a history of creolization that is being utilized for multiethnic and dynamic urban needs in Jakarta and Indonesia. Referring to the Betawi goal to achieve more influence. They must open up to other ethnic groups.

Betawi's alienation from state institutions was striking because of their low social status and the social discrimination they suffered before and after independence. They are becoming more politicized. Many of their organizations have promoted prominent Betawi figures to become their governors. They stated that as a native of Jakarta, they should become official representatives in the national capital. As a result of this recognition, Betawi ethnicity becomes insufficient if they only become indigenous people, as in the past, and increasingly play an active role in politics both at the local and national levels.

While their culture and identity have a creole background, their location in the middle of a heterogeneous capital city may surpass other cultures. It serves as a symbol of Bhinneka Tunggal Ika and effectively represents the complexities of Jakarta and Indonesia. However, there is still a need for a fairly large step from history to political power at the national levels (Knorr, 2007).

Betawi culture is preserved based on Islamic religion and negates polytheism's potential though, in reality, there are more socio-cultural practices such as the third or seventh month of pregnancy, which are not taught in Islam (Iskandar \& Fasta, 2015). Interesting things about Betawi are grouped into the following five sections according to the results of observations 
from Suswandari's previous research, after working with historians, local Betawi communities, and educational practitioners in the context of the study. He interviewed Betawi historians, reviewed literature on the Betawi ethnicity, and studied their artifacts. Also, by observing the Betawi people in their community and interacting with them. From the data collection method, he highlighted five aspects that represent Betawi local beliefs, values , and wisdom, and interestingly, these five aspects are similar to those described in Suswandari (2017). They are included in table 1 below:

Table 1 Belief, Values, and Local Wisdom of Betawi Ethnic (Suswantari, 2017)

\begin{tabular}{|l|l|l|}
\hline No & \multicolumn{1}{|c|}{ Aspect } & \multicolumn{1}{c|}{ Belief, Values, and Local Wisdom } \\
\hline 1 & Religious Value & Religious, religion is embedded in social life, faithful \\
\hline 2 & Language & Cablak (honest is speaking, direct communicators) \\
\hline 3 & Social Interaction & $\begin{array}{l}\text { Tolerant, friendly and plural (admit difference in race, religion), } \\
\text { open minded, democratic, cooperative, humorous, loyal to the } \\
\text { people in the community, empathy, forgiving, social awareness, } \\
\text { dynamic, adaptable, egalitarian }\end{array}$ \\
\hline 4 & Arts & $\begin{array}{l}\text { Creative and Innovative, prose, songs and hum our are used to } \\
\text { promote beliefs and values of Betawi ethnic }\end{array}$ \\
\hline 5 & Self-perfomance & $\begin{array}{l}\text { High confidance, tough, peace, eritical, positive thinker, divergent } \\
\text { thinker,high motivated people. }\end{array}$ \\
\hline
\end{tabular}

\section{THE CONCEPT OF POWER AND THE ISSUE OF ARGINALIZATION IN THE BETAWI TRIBE}

Marginalization or in Indonesian means marginalized is a status for a person or group who is in a relatively powerless and insignificant position in society, sometimes this group is forced to go to distant, undeveloped, and politically insignificant border areas, or it could be These marginalized groups refuse to participate in politics, even in matters affecting their welfare. If this term has been used for a group, it means that that group is considered politically / socially / economically insignificant, excluded, or powerless compared to other societies. Marginalized can also be interpreted as a group that does not dominate but usually submits to a stronger power (Harhara, 2013).

As of 2010, it is known that the Betawi people comprise about $27 \%$ of the population of Jakarta, numbering around 2,700,000, and gather mainly in East and Central Jakarta (Brown \& Wilson, 2007). Betawi is grouped into central Betawi, 'udik' Betawi (Betawi Ora), and suburban Betawi. This classification is done only to clarify the problem when talking about Betawi so that it does not lead to unrepresentative conclusions. Those who belong to the central Betawi normally lives in parts of Central Jakarta. Betawi people usually hide their Betawi identities because mixed marriages between ethnic groups are rather high. Based on their standard of living and their place of life, Betawi people are being divided into "gedong people" and "village people." "Gedong people" are not recognized and acknowledged by outsiders. Their image is closely attached to being highly educated, both to the older generation and the younger generation, even many of their children go to school abroad. It is different from the "village people" whose lifestyle as Betawi people can be observed by outsiders. 
On the other hand, Betawi Udik (Betawi Ora) lives around Jakarta, covering Bogor, Tangerang, and Bekasi. This is because the area was the administrative area of Batavia, which was affected by administrative boundaries changes. Betawi udik has two types; (1) those who live in the north, west, and Tangerang are very influenced by Chinese culture, (2) those who live in the east, south, Bekasi, and Bogor are very influenced by Sundanese culture. Betawi udik is relatively left behind in education and modern work involvement than other Betawi people so that many do not finish their school. In terms of religion, they are generally not fanatical adherents of Islam.

If Central Betawi is more oriented towards higher general education, Betawi Pinggir is more directing religious education like pesantren. As a result, the Islamic characteristics of the Betawi margins remain prominent and persist. Even at Darul Ulum Madrasah in Saudi Arabia, which is very famous for Indonesian students who deepen their Islamic knowledge, the majority are occupied by Betawi people. They dominate the places where they live in Mampang Prapatan, Tegal Parang, Warung Buncit, Gandaria, Pasar Minggu, Rawa Belong, and Basmol.

Between 1966 - 1977, the Betawi people began to be excluded by city development and many migrants, such as one, for example, the Betawi people in Senayan who had to be displaced for the construction of the Asian Games project (Lukmansyah, 2017). At that time, the governor in charge, Mr. Ali Sadikin, made many breakthroughs by building Jakarta's city to become more modern. Nonetheless, controversies of excluding the Betawi community remain unanswered. The construction of roads and buildings, which taking the land and residents, causes the displacement of the original residents, namely Betawi. Land acquisition is carried out by appeal or by force. Those who do not have a house certificate will not get compensation. This became the primary factor why the Betawi has moved to the outskirt of Jakarta.

This marginalization does not always result in cruelty. Marginalization may come from cultural, political, economic origins, but come from experiences, among others, the deprivation of material within the community's boundaries and the chaos of their authorization structure. Thus, the responses of those who feel marginalized cause them to understand the relationship between their economic deprivation and their loss of social cohesion. With these thoughts and conditions, some activists in marginalized groups began to act on emotions, which initially performed instrumentalist functions, developing in an irrational direction. So they also created a gang called FBR (Betawi Rempug Forum) so that they were not considered to be causing problems and getting jobs. Since then, the FBR is respected by the public, and people do not hesitate to ask for their help. So that FBR is the pride of Betawi and a concrete step to improve their condition. FBR also claims exclusive economic and social rights as representatives of the Jakarta traditional community (Brown \& Wilson, 2007).

\section{CONCLUSION}

In general, accounting principles that prioritize transparency and accountability do have liberal characteristics by looking at the dualism of the balance of profits and losses so that the dimensions of the presentation of financial statements are two-dimensional. To see the interests of the community and the environment, a qualitative method is required in presenting the report, so that currently many sustainability reporting reports are required by the capital market. Although the involvement of the 'other side' of accounting for the community has not been optimally accommodated, this is based on the spirit of developing the fundamental accounting epistemology. The marginalization experienced by the Betawi people currently occurs in several dimensions in the form of economic, political, and social and the development of Jakarta as the capital city of Indonesia, which uses the land where they originally lived. The compensation they get is used to buy a place to live on the outskirts of Jakarta, coupled with the deteriorating economy of the Betawi people, it triggers them to be lazy to study politics, and 
not infrequently, they do not know the rights they can fight for. Even though they were born and went to school in urban Jakarta, their ability is only limited, and automatically with their financial capabilities, they can only buy houses on the outskirts of Jakarta, some of them can only live outside Jakarta.

The important role of the government is due to the deteriorating financial condition of Betawi today, which is caused by many very diverse factors. What was previously caused by the extortion of taxes imposed on the community, then the large scale land acquisition carried out by the governor at that time, after independence, impacted the Betawi people who were marginalized from Senayan and several other areas. Development should have been carried out by taking into account the factors of survival and preservation of Jakarta's original ethnic groups. Easily getting rewards from the proceeds from the sale of assets without sustainability education, causing Betawi seniors to prefer to sell their land assets for survival.

With the newcomers' existing expertise and the capital they had, the newcomers became the new colonizers in the city of Jakarta against the Betawi people. Some of the Betawi descendants followed in their predecessors' footsteps, easily selling their land assets because they were used to living by selling land like their ancestors. Moreover, with their ability and economy, they cannot take advantage of the land assets, such as building several rented houses and leasing them to the migrants and the government's lack of regulations that limit land ownership in Jakarta. So that Betawi people who are indigenous people easily release their land to the immigrants.

Another factor that most Betawi face is that the younger generation needs to preserve their own culture, ancestors' legacy, and homeland. In the future, the government and the younger generation will be better at developing financial management and awareness, especially the Betawi people, to preserve the Betawi people in the land of Jakarta and foster a sense of being active in advancing the Jakarta administration.

\section{REFERENCES}

[1] Ahrens, T., \& Mollona, M. (2007). Organisational control as cultural practice-A shop. Accounting, Organizations and Society, 32, 305-331.

[2] Ahyat, I. S. (2015). Dinamika Wanita Betawi pada Abad ke-20. ATIKAN: Jurnal Kajian Pendidikan, Vol.5 (1) June, pp.65-76.

[3] Badan Pusat Statistik. (2019). Retrieved from www.jakarta.bps.go.id: https://jakarta.bps.go.id/dynamictable/2019/09/16/58/jumlah-penduduk-provinsi-dki-jakartamenurut-kelompok-umur-dan-jenis-kelamin-2018-.html

[4] Breton, G. (2018). Sociology of Accounting. In G. Breton, A Postmodern Accounting Theory (pp. 115-131). USA: Emerald Publishing Limited.

[5] Brown, D., \& Wilson, I. D. (2007). Ethnicized Violence in Indonesia: Where Criminals and Fanatics Meet. Nationalism and Ethnic Politics, 13:3, 367-403. Doi: $10.1080 / 13537110701451579$

[6] Darmayasa, I. N., \& Aneswari, Y. R. (2015). Paradigma Interpretif pada Penelitian Akuntansi Indonesia. Jurnal Akuntansi Multiparadigma, 15. Retrieved from https://jamal.ub.ac.id/index.php/jamal/article/view/385

[7] Ekasari, K. (2013). Marjinalisasi Nilai-Nilai Kemanusiaan dalam Pendidikan Akuntansi di Pendidikan Tinggi Vokasi: Tinjauan Kritis dari Perspektif Harbermas. Prosiding Simposium Nasional Akuntansi Vokasi ke-2. Politeknik Negeri Bali, 17 - 18 Mei 2013. Retrieved from 
Marginalization and Significance of Power in Accounting; a Case Study of the Betawi Tribe Society in Indonesia

http://digilib.mercubuana.ac.id/manager/t!@file_artikel_abstrak/Isi_Artikel_271685575022.pd f

[8] Harhara, S. H. (2013, January 30). Marginalisasi: Sebuah Telaah Filosofi dan Sejarah. Retrieved from Academia.edu: https://uinjkt.academia.edu/SayugoHarunHarhara

[9] Iskandar, D., \& Fasta, F. (2015). https://doi.org/10.1108/09513579910259942. Second International Conference On Media, Communication And Culture (ICMCC 2015), 30 Nov. - 2 Dec. 2015, Vistana Hotel. Penang. Retrieved from http://malrep.uum.edu.my/rep/Record/my.usm.eprints.31919

[10] Kamayanti, A. (2017). Akuntan(Si) Pitung: Mendobrak Mitos Abnormalitas dan Rasialisme. Jurnal Riset dan Aplikasi: Akuntansi dan Manajemen. Retrieved from http://jraam.polinema.ac.id/index.php/jraaml/article/view/176

[11] KBBI. (2020, November 11). Retrieved from www.kbbi.web.id: https://kbbi.web.id/marginalisasi

[12] Knörr, J. (2007). Creole Identity and Postcolonial Nation-Building Examples from Indonesia and Sierra Leone. Série Antropologia, Departamento de Antropologia, Universidade de Brasília. Retrieved from https://d1wqtxts1xzle7.cloudfront.net/58189460/Serie_Anthropologia_2007_creole_identity_a nd.pdf? $1547558270=$ \&response-content-

disposition=inline \%3B + filename\%3DCreole_identity_and_postcolonial_nation.pdf\&Expires= $1607156274 \&$ Signature $=\mathrm{dUyg} Y$ rRo6geKp0d79dBruewC

[13] Laughlin, R. (1999). Critical Accounting: Nature, Progress, and Prognosis. Accounting Auditing \& Accountability Journal, Vol 12 No 1, MCB University Press, 73-78. doi:https://doi.org/10.1108/09513579910259942

[14] Lukmansyah, N. (2017). Pengaruh Pembangunan di Jakarta terdahap Sosial Ekonomi Masyarakat Betawi Tahun 1966-1977. Semarang: Fakultas Ilmu Sosial, Universitas Negeri Semarang. Retrieved from http://lib.unnes.ac.id/31695/1/3111412009.pdf

[15] Lukmansyah, N. (2017). Pengaruh Pembangunan di Jakarta terhadap Sosial Ekonomi Masyarakat Betawi Tahun 1966-1977. Universitas Negeri Semarang, Semarang. Retrieved from https://lib.unnes.ac.id/31695/1/3111412009.pdf

[16] Mardiyah, A. A. (2003). Filsafat Ilmu Sebagai Dasar dan Arah Pengembangan Ilmu: Sebuah Pendekatan dengan Metodologi Akuntansi Positif. Jurnal Bisnis dan Akuntansi. Vol 5, No 2, $\begin{array}{lllll}\text { Agustus } & 2003, & \text { 167-169, } & \text { Retrieved }\end{array}$ https://jurnaltsm.id/index.php/JBA/article/view/561

[17] Morgan, G. (1988). Accounting as Reality Construction: Towards a New Epistemology for Accounting Practice. Accounting Organizations and Society, Vol. 13, No. 5, pp. 477---485. doi:https://doi.org/10.1016/0361-3682(88)90018-9

[18] Mursy, A. L., Triyunono, I., \& Rosidi. (2014). Eksplorasi Makna Laba dengan Pendekatan Etnografi. Jurnal Aplikasi Manajemen, Vol 12, No 3. Brawijaya Univeristy. Retrieved from https://jurnaljam.ub.ac.id/index.php/jam/article/view/693/675

[19] Pearlman, J. E. (1975). Rio's Favelas and the Myth of Marginality. Sage Journals Volume: 5 issue: 2, page(s): 131-160. doi:https://doi.org/10.1177/003232927500500201 
[20] Pellokilla, J. M. (2020, Juni 8). Marginalisasi Terhadap Minoritas. Retrieved from www.kompasiana.com:

https://www.kompasiana.com/opajappy/552a98aff17e613625d623c9/marginalisasi-terhadapminoritas-di-indonesia

[21] Pratama, K. G., \& Utomo, D. C. (2018). Meta-Analisis Penelitian Akuntansi di Indonesia. Diponogoro Journal of Accounting. Volume 7, Nomor 4, Tahun 2018, 10.

[22] Pratama, K. G., \& Utomo, D. C. (2018). Meta-Analisis Penelitian Akuntansi di Indonesia. Diponegoro Journal of Accounting. Volume 7, Nomor 4, Tahun 2018, Halaman 1, 10. Retrieved from https://ejournal3.undip.ac.id/index.php/accounting/article/view/25576

[23] Pratama, K. G., \& Utomo, D. C. (2019, November 15). Meta-Analisis Penelitian AKuntansi di Indonesia Periode Tahun 2014 - 2016. Diponegoro Journal of Accounting. Retrieved from https://ejournal3.undip.ac.id/index.php/accounting/article/view/25576

[24] Purbasari, M. (2010). Indahnya Betawi. Jurnal Binus, 1.

[25] Roslender, R. (2002). Sociological Perspectives on Modern Accountancy. London: Roudledge. Retrieved from https://www.taylorfrancis.com/books/9780203404003

[26] Sukoharsono, E. G. (2005). A Critical Perspective Analysis of Indonesian Accounting Thought: Some Preliminary Thoughts on The Search for Better Understand of Accounting in Practice. The International Journal of Accounting and Business Society. Brawijaya University. Retrieved from https://ijabs.ub.ac.id/index.php/ijabs/article/view/114/143

[27] Suswandari, S. (2017). Incorporating Beliefs, Values and Local Wisdom of Betawi Culture in a Character-Based Education Through a Design-Based Research. European Journal of Contemporary Education, 6(3), 574-585. Retrieved 1 7, 2020, from http://files.eric.ed.gov/fulltext/ej1154719.pdf

[28] Wickramasinghe, D., \& Hopper, T. (2005). A cultural political economy of management accounting controls: a case study of a textile Mill in a traditional Sinhalese village. Critical Perspectives on Accounting, 16, 473-503.

[29] Wickramasinghe, P. D. (2006). Researching Power in Accounting. London: Spiramus. Retrieved from http://eprints.gla.ac.uk/67825/ 